\title{
Severe gastrointestinal strongyloidiasis
}

Estrongiloidiose gastrointestinal grave

\section{José Roberto Lambertucci', Mateus Rodrigues Westin ${ }^{1}$ and Alfredo José Afonso Barbosa ${ }^{2}$}

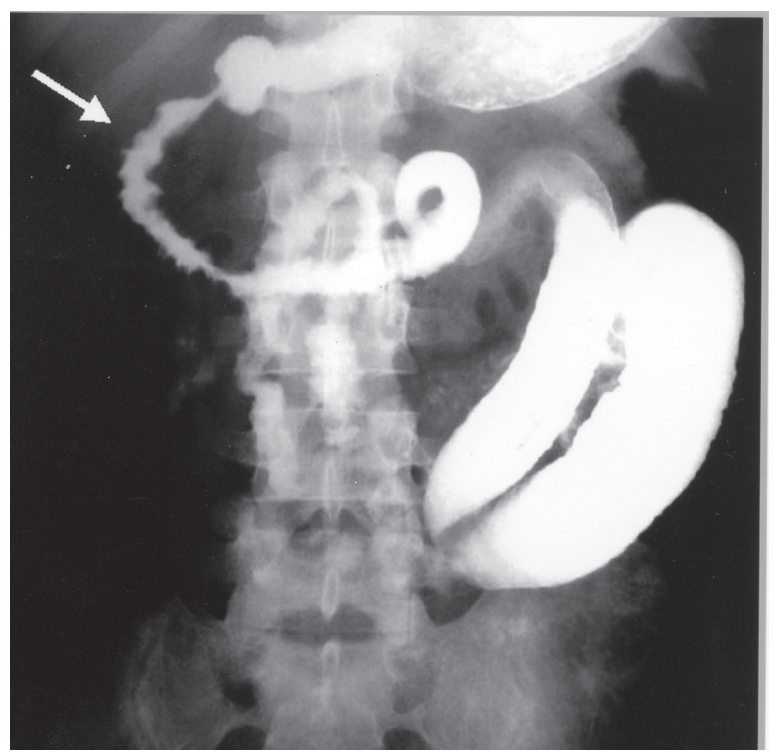

A

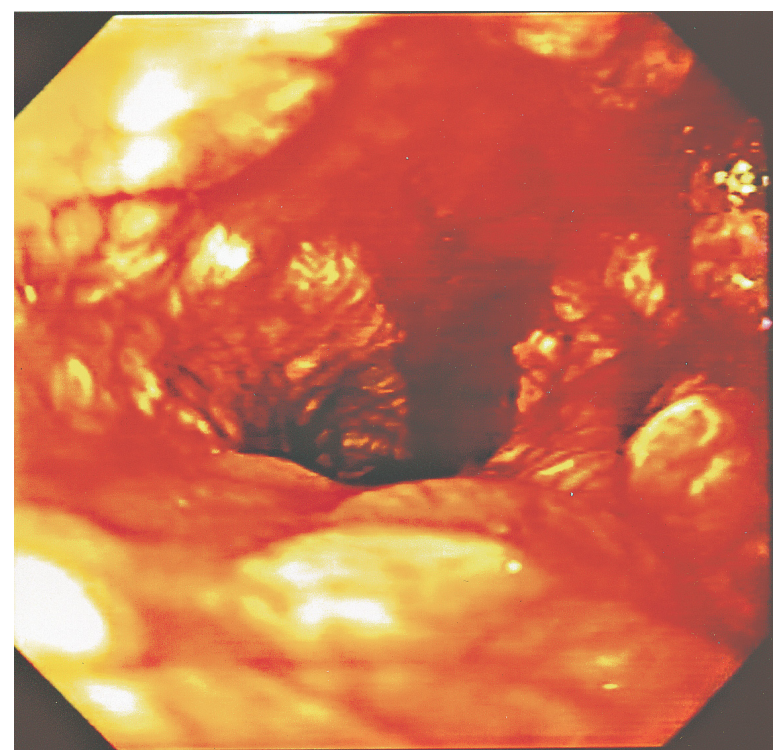

B

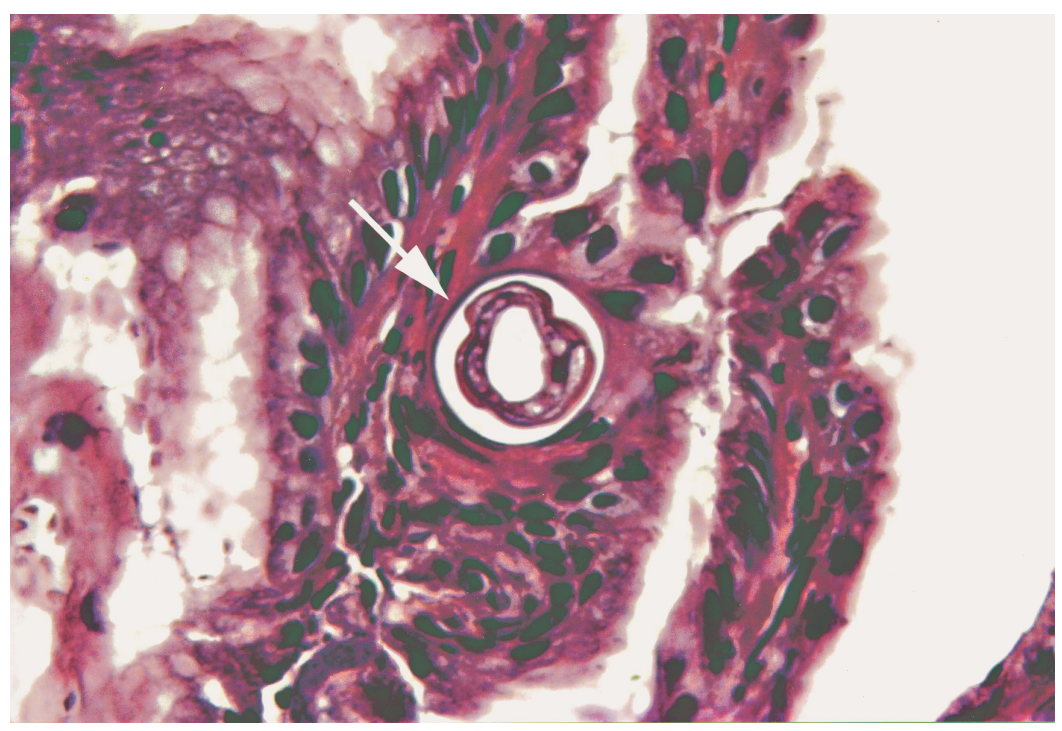

$\mathrm{C}$

1. Serviço de Doenças Infecciosas da Faculdade de Medicina da Universidade Federal de Minas Gerais, Belo Horizonte, MG. 2. Departamento de Anatomia Patológica da Faculdade de Medicina da Universidade Federal de Minas Gerais, Belo Horizonte, MG.

Address to: Prof. José Roberto Lambertucci. Faculdade de Medicina/UFMG. Avenida Alfredo Balena 190, 30130-100 Belo Horizonte, MG, Brasil.

e-mail: lamber@uai.com.br

Recebido para publicação em 7/4/2005

Aceito em 3/5/2005 
A 26-year-old man was admitted to hospital complaining of colic abdominal pain, nausea, vomiting and diarrhea, which started 9 days before. He has been receiving prednisone ( $80 \mathrm{mg} /$ day) for the last 2 months for the treatment of schistosomal myeloradiculopathy and omeprazole for gastric protection. He was also treated for strongyloidiasis with ivermectin (12mg, single dose) before starting prednisone. His clinical condition deteriorated rapidly after admission, with severe vomiting, dehydration, hyponatremia $(115 \mathrm{mEq} / \mathrm{L})$, hypoalbuminemia $(0.9 \mathrm{~g} / \mathrm{dl})$ and paralytic ileus. A urinary tract infection, caused by Escherichia coli, was diagnosed and treated with ciprofloxacin. Fifteen days after admission, parenteral nutrition was initiated. A gastrointestinal contrasted radiograph was performed and it showed a dilated stomach and stricture of the lumen of duodenum and jejunum ( Figure A- arrow). Upper endoscopy revealed a moderate enanthematous gastritis and in the antrum and duodenum it was described a friable mucosa with bleeding, edema and elevated whitish areas (Figure B). Biopsies of the esophagus, stomach and duodenum were obtained and submitted to histological examination. In the stomach a great number of larvae of Strongyloides were identified (Figure C - the arrow points to a larva of Strongyloides), and they were surrounded by inflammatory cells and eosinophils. The patient was treated with ivermectin (12mg, single dose) followed byalbendazole ( $400 \mathrm{mg} /$ day) for 10 days and improved over the following 8 days. Two months later, at the outpatient clinic, he was feeling well. Strongyloides larvae were still found in his stools. He received albendazole (400/day) again for 30 days and remains asymptomatic.

0 paciente, de 26 anos, foi admitido ao hospital queixandose de dor abdominal em cólica, náuseas, vômitos e diarréia de início havia nove dias. Ele vinha sendo tratado com prednisona ( $80 \mathrm{mg} /$ dia), nos últimos dois meses, com 0 diagnóstico de mielorradiculopatia esquistossomótica e omeprazol para proteção gástrica. Ele havia recebido, ainda, ivermectina ( $12 \mathrm{mg}$, em dose única) para 0 tratamento de estrongiloidíase antes de iniciar a prednisona. Após a admissão hospitalar, 0 quadro clínico piorou rapidamente, com vômitos persistentes, desidratação, hiponatremia $(115 \mathrm{mEq} / \mathrm{L})$, hipoalbuminemia $(0,9 \mathrm{~g} / \mathrm{dl})$ e íleo paralítico. Diagnosticou-se infecção urinária, causada pela Escherichia coli, que foi tratada com ciprofloxacina. Iniciou-se nutrição parenteral 15 dias após a internação. 0 trânsito intestinal evidenciou dilatação do estômago e estenose das luzes do duodeno e jejuno. ( Figura A - seta). A endoscopia digestiva alta revelou gastrite enantematosa moderada, e, no antro e duodeno, a presença de mucosa friável, sangrante, edematosa e com placas elevadas e esbranquiçadas ( Figura B). Os fragmentos de esôfago, estômago e duodeno, obtidos por biópsias, foram encaminhados para exame histológico. Descreveu-se no estômago a presença de larvas de Strongyloides ( Figura C - a seta aponta uma larva de Strongyloides), envolvidas em processo inflamatório contendo eosinófilos. 0 paciente foi tratado com ivermectina (12mg, em dose única) , seguido de albendazol ( $400 \mathrm{mg} / \mathrm{dia}$ ) por 10 dias e houve melhora marcante ao longo dos próximos oito dias. Dois meses mais tarde, em ambulatório, ele sentia-se bem. As larvas de Strongyloides ainda foram encontradas nas fezes. Ele recebeu albendazol (400mg/dia) por 30 dias e permanece assintomático.

\section{REFERENCES}

1. Benhur Junior A, Serufo JC, Lambertucci JR. Pulmonary strongyloidiasis. Revista da Sociedade Brasileira de Medicina Tropical 37: 359-360, 2004.

2. Lambertucci JR, Leão FC, Barbosa AJA. Gastric strongyloidiasis and infection by the human T cell lymphotropic virus type 1 ( HTLV-1). Revista da Sociedade Brasileira de Medicina Tropical 36: 541-542, 2003.

3. Porto MAF, Muniz A, Oliveira Júnior J, Carvalho EM. Implicações clínicas e imunológicas da associação entre o HTLV-1 e a estrongiloidíase. Revista da Sociedade Brasileira de Medicina Tropical 35: 641-649, 2002. 